\title{
Seed and pollen study of taxa belonging to the genus Eruca Miller in relation to some characters present in species of the genus Diplotaxis DC.
}

\author{
Walter De Leonardis ${ }^{1}$ \\ Carmelinda De Santis ${ }^{1}$ \\ Girolamo Fichera ${ }^{1}$
}

and

\author{
Stefano Padulosi ${ }^{2}$ \\ ${ }^{1}$ Botany Department, University Catania, Italy. \\ ${ }^{2}$ International Plant Genetic Resources Institute (IPGRI), ICARDA, Aleppo, Siria.
}

De Leonardis W., De Santis C., Fichera G. \& Padulosi S. 2002. Seed and pollen study of taxa belonging to the genus Eruca Miller in relation to some characters present in species of the genus Diplotaxis DC. Taeckholmia 22(2):177187.

The authors analyzed the seeds and pollen of three taxa belonging to the genus Eruca Miller (E. pinnatifida (Desf.) Pomel f. aurea (Batt.) Maire, E. sativa Miller, E. vesicaria (L.) Cav. using OM and SEM. The study of morphobiometric data identified three morphotypes and an identification key was elaborated. The length of the polar axis of the pollen grains and the length of the seeds represent the primary characters for distinguishing the taxa of Eruca and those belonging to the genus Diplotaxis observed in a previous study (De Leonardis et al., 2002). Further characters are the thickness of the sexine (more accentuated in Diplotaxis) and the different disposition of the seed coat reticulum. Moreover, based on the palynological and seminal characters found the close affinity between Eruca vesicaria and E. sativa confirmed the systematic placing proposed by Tutin et al. (1964) who placed them in E. vesicaria (L.) Cav. ssp. vesicaria and E. vesicaria (L.) Cav. ssp. sativa (Miller) Thell. respectively. The two taxa had a greater affinity with respect to E. pinnatifida f. aurea that is nearer to the group of taxa belonging to the genus Diplotaxis as can be seen from the examination of the dendrogram.

Key words: pollen, seed, Eruca, Diplotaxis.

\section{Introduction}

The name "rocket" is normally used to indicate botanical species belonging to the genera Eruca Mill. and Diplotaxis DC. of the Brassicaceae. These are annual and perennial herbs that were known during the Roman period for their aphrodisiac properties (Fernald, 1993) and whose leaves have been traditionally used both in cooking and in pharmacopoeia due to their antiphlogistic, astringent, depurative, diuretic digestive, emollient, tonic, and laxative properties (Tonzig, 1941; Beijerink, 1947; Garnier, 1961; Arietti, 1965; Uphorf, 1968; Ellison et al., 1980; Maugini, 1973; Tomaselli, 1974; Balbé, 1978; De Capite, 1984; Gastaldo, 1987; Mascagno, 1987; Anonymous, 1988 and 1991; Biagi \& Sperone, 1988; Anzalone, 1989; De Feo \& Senatore, 1993).

Over the last few years studies have investigated the vitality and germinability of their seeds, gametophytic selection, etc. which could be useful to improve and/or safeguard the genetic diversity of numerous species belonging to the family of Brassicaceae that, for a long time, have been underused (Morinaga, 1934; Labana et al., 1977; Gorini, 1979; Arora \&

Received 20 September, 2002. Revision accepted 24 October, 2002. 
Lamba, 1980; Goth \& Webb, 1980; Lamba \& Arora, 1981; Des \& Lal, 1982; Matsuzawa \& Sarashima, 1986; Mascagno, 1987; Kanthaliya et al., 1990; Hammer et al., 1992; Anonymous, 1993). Various contributions were presented at the workshop in Padova (A.A.V.V., 1996) on the "rocket" species examining genetic resources, cross-pollination, cultivation and the world status of the "rocket" species. Genebank collections were also made (Gatersleben (IPK), Braunschweig (FAL) in Germany; IdG in Italy; Wellsbourne (HRI) in UK; Iowa (USDA) in USA to safeguard the species belonging to the two genera.

In this study the authors examined the seeds and pollens from three taxa of the genus Eruca, viz. E. pinnatifida (Desf.) Pomel f. aurea (Batt.) Maire, E. sativa Miller, and E. vesicaria (L.) Cav.) to characterize the morphology and biometry, as well as to correlate these data with those already available relevant to the genus Diplotaxis (De Leonardis et al., 2002) so as to identify further diacritic characters between the two genera.

\section{Materials and Methods}

The anthers were acetolysed according to Erdtman (1960) and conserved in a glycerine: water solution (1:1). Pollen and seeds were observed using a Zeiss standard LM with 100x objective (N.A. 1.30) equipped with 10x eyepieces and a stereomicroscope Galileo equipped with an ocular micrometer respectively.

For the observations by SEM (JEOL-JSM 35) pollens and seeds were washed, dehydrated, dried by critical point, affixed to alluminium stubs with double stick and coated

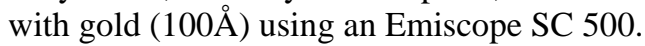

Pollens grains were designated using the terminology of Erdtman (1969 and 1971) and De Leonardis et al. (1986), while seeds were designated following the works of Stearn (19739, Berggren (1981). The seed colour was scored according to Kornerup \& Wanscher'manual (1978). Seed material of the 3 taxa belonging to the genus Eruca was provided by Professors Gómez-Campo and Martínez Laborde of the Polytechnic University of Madrid, Spain. Full names of species used in the text are those adopted by the institutions providing the germplam. The material (seed and pollen) is preserved at the Department of Botany, University of Catania, Italy.

\section{Abbreviations adopted in the text:}

$\mathbf{P}=$ polar axis $\mathbf{E}=$ equatorial axis; $\mathbf{P c}=$ measure colpus in polar direction; $\mathbf{E} \mathbf{c}=$ measure colpus in equatorial direction; Psex = sexine thickness in polar view; Pnex = nexine thickness in polar view; Esex = sexine thickness in equatorial view; Enex = nexine thickness in equatorial view; $\mathbf{M e s}=$ mesocolpium; $\mathbf{L T P}=$ polar triangular side; $\mathbf{P l u m}=$ diameter lumen in polar view; Elum = diameter lumen in equatorial view; Pmu = polar muri thickness; Emu = equatorial muri thickness; $\mathbf{L}=$ lenght; $\mathbf{W}=$ width; $\mathbf{T}=$ thickness.

Population codes reported in the dendrogram: Eruca pinnatifida f. aurea: P01, P02, P03, P04; E. vesicaria: V05, V06, V07, V08; E. sativa: S09, S10, S11, S12.

As concerns the correlation with the taxa belonging to the genus Diplotaxis the species that had the widest biometric variability intervals were considered: Diplotaxis muralis (L.) DC. (D13); D. catholica (L.) DC. (D14); D. brachycarpa Godr. (D15) and D. viminea (L.) DC. (D16). 


\section{Results}

The pollen was characterized by isopolar radiosymmetric monads, with three longitudinal colpal apertures and with the thickness of the sexine and nexine constant. According to the typing present in the Brassicaceae described by De Leonardis et al. (1989) the polar lumina are of the finely reticulate-mediumreticulate type while the equatorial ones include the medium reticulate-reticulated types in E. pinnatifida f. aurea, finely reticulate-medium reticulate in E. vesicaria, finely reticulate-reticulate in $E$. sativa.

The seeds showed a tegument characterized by a reticulum with poorly prominent walls in E. pinnatifida f. aurea and prominent in E. sativa and E. vesicaria.

Based on the morphological and biometric characters, both palynological and seminal, it is possible to define three morphotypes.

\section{Eruca pinnatifida f. aurea type}

Pollen $(\mu \mathrm{m})$

$\mathrm{P}=18(19) 20$

$\mathrm{E}=18(20) 21$

$\mathrm{Pc}=12(14) 16$

$\mathrm{Ec}=2.0(2.6) 3.0$

Psex $=0.67(0.86) 0.90$

Pnex $=0.67(0.70) 0.90$

Esex $=0.6780 .88) 0.90$

Enex $=0.67(0.85) 0.90$

Mes $=11(12) 13$

LTP = 3.6(4.0)4.5 circular lumina

Plum $=0.45(0.50) 0.67$

Elum $=0.67(0.80) 1.3$

$\mathrm{Pmu}=0.45$

$\mathrm{Emu}=0.45$

\section{Eruca sativa type}

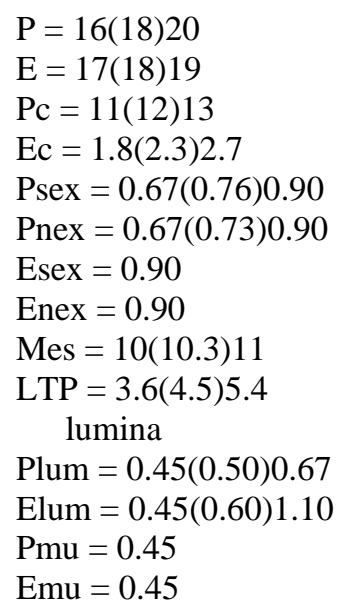

Seed (mm)

Shape: ovate

Side outline: elliptical

Transversal outline: tightly elliptical

Radicular shape: 0.25 wide

Radicular extremity: as long as the cotyledoonous, subobtuse

Cotyledonous extremity: subobtuse

Basal cut: very evident

Radicular and cotyledonous furrow: very evident

Hilum and micropile: covered with a wide wing of funicular tissue Tegument: regular reticulum, poco prominente with

Colour: egg yellow

$$
\begin{aligned}
& \mathrm{L}=1.40(1.47) 1.55 \\
& \mathrm{~W}=0.90(0.99) 1.05 \\
& \mathrm{~T}=0.50(0.55) 0.60
\end{aligned}
$$

Shape: from ovate to widely elliptical

Side outline: widely elliptical

Transversal outline: from subcircular to subrhombic

Radicular shape: 0.30 wide

Radicular extremity: as long as the cotyledoonous, curved, subacute

Cotyledonous extremity: subobtuse

Basal cut: very evident

Radicular and cotyledonous furrow: very evident

Hilum and micropile: covered with funicular tissue

Tegument: regular reticulum, prominente with subcircular

Colour: from yellow brown to green olive

$$
\begin{aligned}
& \mathrm{L}=1.35(1.44) 1.50 \\
& \mathrm{~W}=0.95(1.04) 1.10 \\
& \mathrm{~T}=0.75(0.80) 0.85
\end{aligned}
$$




\section{Eruca vesicaria type}

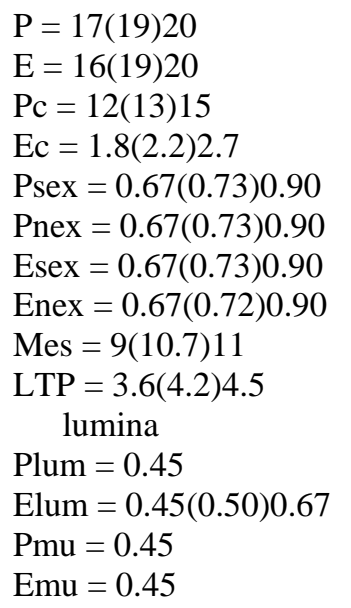

Shape: from widely elliptical to widely ovate

Side outline: widely elliptical

Transversal outline: subcircular

Radicular shape: 0.30 wide

Radicular extremity: as long as the cotyledoonous, subacute

Cotyledonous extremity: subobtuse

Basal cut: very evident

Radicular and cotyledonous furrow: very evident

Hilum and micropile: covered with funicular tissue

Tegument: irregular reticulum, prominente with irregular

Colour: from yellow brown to green olive

$\mathrm{L}=1.30(1.35) 1.45$

$\mathrm{W}=0.80(0.83) 0.90$

$\mathrm{T}=0.70(0.77) 0.85$

\section{Key for pollen and seed (including Diplotaxis speciea):}

1.a. Pollen with a polar axis $>20 \mu \mathrm{m}$, equatorial sexine thickness $>1.3 \mu \mathrm{m}$, seed length $\leq 1.20 \mathrm{~mm}$

Diplotaxis spp

b. Pollen with a polar axis $\leq 20 \mu \mathrm{m}$, equatorial sexine thickness $\leq 0.90 \mu \mathrm{m}$, seed length $>1.30 \mathrm{~mm}$

2.a. Pollen with a mesocolpium width11-13 $\mu \mathrm{m}$, seeds with transversal outline tightly elliptical, tegument with poorly prominent reticulum walls

E. pinnatifida f. aurea type

b. Pollen with a mesocolpium width119-11 $\mu$ m, seeds with different tran-sversal outline, tegument with prominent reticulum walls

3.a. Pollen with equatorial thickness of the sexine and nexine $0.67-0.90 \mu \mathrm{m}$, seed width 0.80-0.90 mm, subcircular transversal outline, irregular lumina outline

E. vesicaria

b. Pollen with equatorial thickness of the sexine and nexine $(0.9 \mu \mathrm{m})$, seed width $0.95-1.10 \mathrm{~mm}$, from subcircular to subrhombic transversal outline, with subcircular lumina

E. sativa

\section{Discussion}

From the palynological point of view there are many studies on the Brassicaceae family but these refer only to the taxa isolated without an exhaustive palynological reading with respect to that of other families (e.g. Kapp, 1969; Arobba, 1976; Aytug et al., 1971; Faegri \& Iversen, 1975; Perez De Paz, 1977; Moore \& Webb, 1978; Rollins \& Banerjee, 1979; De Leonardis et al., 1984, 1986a, 1989, 1989a and 1990; Lahham \& Al-Eisawi, 1987).

In particular, as regards the genus Eruca, Díez (1987) included in the type Raphanus raphanistrum the pollen of E. sativa characterized by a lumina of the reticulate type (1.0-1.5 $\mu \mathrm{m})$ and by polar and equatorial axes of $15-22 \mu \mathrm{m}$ and $15-19 \mu \mathrm{m}$ respectively. El Naggar (1988) on samples of E. sativa from Egypt reported axes, polar and equatorial, of $33 \mu \mathrm{m}$ and $17 \mu \mathrm{m}$ respectively, reticulum of the microreticulate type with a lumina $<1.0 \mu \mathrm{m}$ and wall 
thickness of $0.7 \mu \mathrm{m}$. Our data confirm, in part, those of the two above mentioned authors though with notably different values, presumably average, of the polar axis reported by El Naggar. If we compare, palynologically, the biometric and morphological data of the three taxa of Eruca with those observed in different species of the genus Diplotaxis (De Leonardis et al., 2002) the primary character in the distinction of the two genera is the length of the polar axis that in Eruca is in the range 16-20 $\mu \mathrm{m}$ with an average value of $19 \mu \mathrm{m}$, while in Diplotaxis it is $20-31.5 \mu \mathrm{m}$ with average values in the range $22-27 \mu \mathrm{m}$. Really the distinguishability would be greater if we took into consideration $D$. muralis with polar axes of 31-38 $\mu$ m. This species $(\mathrm{n}=21$ e $\mathrm{n}=22$ in Pignone \& Galasso, 1995), considered a hallopolyploid among $D$. tenuifolia $(\mathrm{n}=11)$ and $D$. viminea $(\mathrm{n}=10)$ (Harberd \& McArthur, 1972), has a greater dimensional increase with respect to the parent species as well as a dimensional dimorphism, presence of tetracolpate granules, tendancy of an irregular distribution of the colpi, and aborted granules.

Persano Oddo \& Ricciardelli D’Albore (1989) defined 450 melissopalynological types belonging to 133 families and, limited to only Cruciferae, they distinguished Brassica $\mathrm{f}$. $<20 \mu \mathrm{m}$, Brassica f. 20-25 $\mu \mathrm{m}$, Brassica f. $>25 \mu \mathrm{m}$, Sinapis f. and Matthiola. For the values of the polar axis that we observed in taxa belonging to the genus Eruca (16-20 $\mu \mathrm{m})$ it would be opportune to correct the scale of the intervals.

Furthermore, the thickness of the sexine $(1.3-2.2 \mu \mathrm{m})$ more accentuated in Diplotaxis represents a further character for distinguishing between the two genera.

If we consider the evolutive tendency that is the most accepted in palynology (Punt, 1967, 1971 and 1976; Walker \& Doyle, 1975; De Leonardis et al. 1999) we can hypothesize a more evolved status in Diplotaxis with respect to the genus Eruca, this event is due to the increased dimensions of the pollen grains, the greater length of the colpi, the thickness of the exine, the dimensions of the lumina and the thickness of the muri. However, Blangiforti \& Venora (1996), from the karyotypic investigation of E. vesicaria ssp. sativa (Mill.) Thell., E. vesicaria ssp. pinnatifida (Desf.) Emb. and Maire and Diplotaxis tenuifolia (L.) DC. (all with $\mathrm{n}=22$ in agreement with Warwick and Anderson, 1993), hypothesize a status relatively more evolved for the two taxa of Eruca with respect to D. tenuifolia.

Little has been done relative to the study of the ornamentation of the tegument of the seeds belonging to the genus Eruca. Tegument of Brassicaceae, has been found to be a useful intergenus and/or infraspecies diacritic character with a evolutive tendency. In one study on the genus Sinapis and Brassica nigra De Leonardis \& Fichera (1994) showed how this character is a useful element both for the evaluation of the taxonomic placing of the species and for the diagnosis for the sophistication of the seeds.

From the morphological and anatomical examination of 90 genera and 200 species of this family Vaughan \& Whitehouse (1971) observed in E. vesicaria ssp. vesicaria and E. vesicaria ssp. sativa, a seed length of $2.0 \mathrm{~mm}$ and a slightly reticulate tegument in the former and a length of $2.2 \mathrm{~mm}$ and a smooth tegument in the latter. However, if the biometeric data reported by Vaughan \& Whitehouse (1971) are slightly greater than those observed by us, the observation of the morphology of the tegument that we carried out by SEM is more detailed showing a common reticulate model in the three taxa. In particular, in E. pinnatifida f. aurea it is regular and poorly prominent with a lumina clearly circular, in E. vesicaria it is irregular and prominent with an irregular lumina and in E. sativa it is regular and prominent with a subcircular lumina.

From the comparison of the seeds of Eruca and Diplotaxis we found a greater seed length in Eruca (1.30-1.55 $\mathrm{mm}$ ) that clearly allows it to be distinguished from those belonging to the genus Diplotaxis $(0.60-1.20 \mathrm{~mm})$. Furthermore, the seeds of Diplotaxis have a tegument 
with a reticulum that ranges from irregular to rugulate with muri from subexagonal to very irregular and clearly distinguishable at the base of the reticulum. Between the three taxa of Eruca that we observed that the irregular reticulum E. vesicaria has the most affinity for the group of Diplotaxis. Eruca vesicaria and E. sativa have a clear morphostructural affinity both for pollen and seeds with respect to E. pinnatifida f. aurea, confirming the systematic placing proposed by Tutin et al. (1964) with E. vesicaria (L.) Cav. ssp. vesicaria and E. vesicaria (L.) Cav. ssp. sativa (Miller) Thell.

If we observe the dendrogram (Fig. 1) elaborated on the basis of 16 samples (4 for each taxon), it appears clear both the morphobiometric uniformity of each taxon in the 4 populations and the greater palynological and seminal affinity between E. vesicaria and $E$. sativa with respect to E. pinnatifida f. aurea and, at the same time, the great affinity of the latter for the taxa belonging to the genus Diplotaxis.

\section{References}

A.A.V.V. 1996. Rocket: a Mediterranean crop for the world (Padulosi, S. and Pignone D., eds.). Report of a workshop 13-14 december 1996 Legnaro (Padova), International Plant Genetic Resources Institute, Rome, Italy. 97 pp.

Anonymous. 1988. Il grande libro delle erbe. Peruzzo Editore.

1991. Horta è saude. Editoria Abril, São Paulo, pp. 338

1993 . IV e V gamma: una indagine sulle prospettive di consumo. Ist. Studi Ric. Inf. Mercato Agricolo, Roma, 26 pp.

Anzalone, B. 1989. Botanica Farmaceutica. Japadre, L'Aquila.

Arietti, N. 1965. Flora medica ed erboristica nel territorio bresciano. Commentari Ateneo di Brescia. Tip. Fratelli Geroldi, Brescia. 460 pp.

Arobba, D. 1976. Schede per una Flora Palinologica Italiana. Contributo n.3: Schede di nuova impostazione. Arch. Bot. Biogeogr. It., 20(1/2): 9-56.

Arora, B.B. \& Lamba, L.C. 1980. Structure and dehiscence mechanism of fruit wall in Eruca sativa Mill. An oleiferous crucifer. Curr. Sci., 48(2): 62-64.

Aytug, B., Aykut, S., Merev, N. \& Edis. 1971. Atlas des pollens des environs d'Istambul. Istambul.

Balmé, F. 1978. Plantas Medicinais. Hemus Livraria Editora Limitada, São Paulo. pp. 398.

Beijerink, W. 1947. Zadenatlas der Nederlandsche Flora. Veeman and Zonen, Wageningen.

Berggren, G. 1981. Atlas of seed. $3^{\text {rd }}$ edn. Swedish Museum of Natural History, Stockholm.

Biagi, G.L. \& Speroni, E. 1988. Farmacognosia. Patron, Bologna.

Blangiforti, S. \& Venora, G. 1996. Cytological study on roket species by means of image analysis system. In: Padulosi, S. and Pignone, S. , (Eds.). Rocket: a Mediterranean crop for the world Plant Genetic Resources Institute, Rome, Italy. 36-37 pp.

De Capite, L. 1984. Botanica Farmaceutica. Galeno, Perugia.

De Feo, V. \& Senatore, F. 1993. Medicinal plants and phytotherapy in the Amalfitan coast, Salerno Province, Campania, Southern Italy. J. Ethnopharmacol., 39: 39-51.

De Leonardis, W., Barbera, G., Fichera, G., La Mantia, T., Padulosi, S. \& Zizza A. 1999. Probable evolutive trends on naturalized and cultivated Opuntia Miller entities from Sicily on the basis of morphobiometric pollen and seed characters. Bol. Soc. Brot., 69: 163-180.

De Leonardis, W., De Santis, C., Fichera, G. \& Zizza, A. 2002. Analytic keys and taxonomic considerations based on pollen and seed characters in some species belonging to the genus Diplotaxis L. Bol. Soc. Brot., (in press). 
De Leonardis, W., Duro, A., Piccione, V., Scalia, C. \& Zizza, A. 1984. Flora Palinologica Italiana. Palinoschede di specie endemiche e subendemiche siciliane. Boll. Acc. Gioenia Sci. Nat., 17(324): 495-527.

delle Cruciferae. Inform. Bot. Ital., 21(1/3): 285-290.

\& ---------, 1989. Il reticulum nei pollini \& --------, 1990. Flora Palinologica Italiana. Contributo alla caratterizzazione morfobiometrica delle Cruciferae. Boll. Acc. Gioenia Sci. Nat., 23(336): 515-560.

- \& Fichera, G. 1994. Diagnostic value of seed coat in italian taxa of the genus Sinapis and Brassica nigra. Bol. Soc. Brot., 66(2): 235-244.

, Palmieri-Matarese, R., Piccione, V. \& Zizza, A. 1986a. Morfobiometria pollinica all'O.M., al S.E.M. ed al T.E.M. di specie endemiche siciliane. Boll. Acc. Gioenia Sci. Nat., 19(328): 143-167.

-, Rossitto, M. \& Zizza, A. 1989a. Contributo alla conoscenza di taxa endemici della Sicilia attraverso l'analisi morfobiometrica del polline. Acta Bot. Malac., 14: 117-128.

-------, Piccione, V., Zizza, A. \& Santoro, M. 1986. Flora Palinolgica Italiana. Atlante-Glossario. Boll. Acc. Gioenia Sci. Nat., 19(329): 23-40.

Des, C. \& Lal, P. 1982. Effect of water quality and moisture regime on soil properties and yeld of mustard and taramina (Eruca sativa). J. Indian Soc. Soil Sci., 30: 411-414.

Díez, M.J. 1987. Brassicaceae (Cruciferae). In: Valdés, B., Díez, M.J. and Fernández, I., (Eds.), Atlas polinico de Andalucia Occidental. Sevilla, 154-158 pp.

Ellison, J.A., Hylands, A., Paterson, A., Pick, C., Saneki, K. \& Stuart, M. 1980. Enciclopedia delle erbe. Mondadori, Verona. pp. 303.

El-Naggar, M.S. 1988. Taxonomic studies on Cruciferae in Egypt. 2. Pollen grain morphology of tribe Brassiceae. Taeckholmia, 11: 77-84.

Erdtman, G. 1960. The acetolysis method. Svenk. Bot. Tidskr., 54: 561-564.

-, 1969. Handbook of Palynology. Munksgaard.

, 1971. Pollen morphology and taxonomy. I. Angiosperms. New York.

Faegri, K. \& Iversen, J. 1975. Textbook of pollen analysis. Munksgaard, Copenhagen.

Fernald, M.L. 1993. Gray’s Manual of Botany. $2^{\circ}$. Dioscorides Press, Portland, Oregon. pp. 709.

Garnier, G. 1961. Ressources médicinales de la flore francaise. Vigot Fréres, Paris.

Gastaldo, P. 1987. Compendio della Flora officinale Italiana. Piccin Nuova Libraria, Padova.

Gorini, F. 1979. Rucola o ruchetta o rughetta. Inform. Ortofrutt., 20(11): 5-6.

Goth, R.W. \& Webb, R.E. 1980. Roquette, Eruca vesicaria subsp. sativa a good host for long term maintenance of aphid vectors of potato viruses. J. Am. Potato, 57: 285-289.

Hammer, K., Knüppfer, H., Laghetti, G. \& Perrino, P. 1992. Seeds from the past. A catalog of crop germplasm in South Italy ad Sicily. Istituto del Germoplasma, CNR, Bari, Italy. 173 pp.

Harberd, D.J. \& McArthur, E.D. 1972. The chromosome constitution of Diplotaxis muralis (L.) DC. Watsonia, 9: 131-135.

Kanthaliya, P.C., Sharma, S.L., Singh, G.H. \& Lal, F. 1990. Response of taramina (Eruca sativa) to frequence of irrigation under varying levels of fertility. Trans. Indian Soc. Desert Techn., 117-119. Field Crop. Abstr. (1991) 44:2562.

Kapp, R.O. 1969. How to know pollen ad spores. W.C. Brown CO., Dubuque, Iowa.

Kornerup, A. \& Wanscher, J.H. 1978. Methuen handbook of colour. (ed. 3) Eyre Methuen, London. 
Labana, K.S., Lotay, R.K. \& Kumar, A. 1977. Comparative studies of diploids and tetraploids in Eruca sativa Lam. Crop Improvement, 4(1): 41-47. Field Crop. Abstr. (1979) 32: 4859.

Lahham, J.N. \& Al-Eisawi, D.M. 1987. Pollen morphology of Jordanian Cruciferae. Mitt. Bot. Staatssamml. München, 23: 355-375.

Lamba, L.C. \& Arora, B.R. 1981. Anatomical and morphological studies on field ripe seeds of Eruca sativa Mill. Acta Bot. Indica, 9:88-93.

Mascagno, V. 1987. Coltivata o selvatica la rucola è ottima in insalata. Vita in campagna, 5(12): 42-43.

Matsuzawa, Y. \& Sarashima, M. 1986. Intergeneric hybridization of Eruca, Brassica and Raphanus. Cruciferae. Newsl., 11:17.

Maugini, E. 1973. Botanica farmaceutica. Cusf, Firenze.

Moore, P.D. \& Webb, J.A. 1978. An illustrated guide to pollen analysis. Hodder ad Stoghton, London.

Morinaga, T. 1934. Interspecific hybridization in Brassica VI. The cytology of F1 hybrids of B. juncea and B. nigra. Cytologia, 6: 66.

Perez De Paz, J. 1977. Contribucion al atlas palinologico de endemismos CanarioMacaronesicos. 2. Bot. Macar., 2: 35-39.

Persano Oddo, L. \& Ricciardelli D’Albore, G. 1989. Nomenclatura melissopalinologica. Apicoltura, 5: 63-72.

Pignone, D. \& Galasso, I. 1995. Preliminary results from cytogenetic investigations aiming at characterizing the caryotype of Eruca and Diplotaxis species. In: Padulosi, S., (compiler), Rocket Genetic Resources Network November 1994, Lisbon, Portugal. International Plant Genetic Resources Institute, Rome, Italy. 15-16 pp.

Punt, W. 1967. Pollen morphology of the genus Phyllanthus (Euphorbiaceae). Rev. Palaeobot. Palynol., 3: 141-150.

-, 1971. Pollen morphology of the genera Norantea, Souroubea and Ruyschia (Marcgraviaceae). Pollen et Spores, XIII(2): 199-232.

-, 1976. Evolutionary trends in the grains of Dichapetalaceae. In: Ferguson, I.K. and Muller, J., (Eds.). The evolutionary significance of the exine Academic Press, London and New York. pp.139-146.

Rollins, R.C. \& Banerjee, U.C. 1979. Pollen of the Cruciferae. Harvard University Press.

Stearn, W.T. 1973. Botanical Latin. ed. 2, Newton Abbot.

Tomaselli, R. 1974. Botanica Farmaceutica. Libreria Internazionale Garzanti, Pavia.

Tonzig, S. 1941. Botanica Farmaceutica e Veterinaria. La Grafolito, Bologna.

Tutin, T.G. 1964. Flora Europaea.1․ Cambridge.

Uphorf, J.C.T. 1968. Dictionary of Economy Plants. Verlag Von J. Cramer Publ., New York. $591 \mathrm{pp}$.

Vaughan, J.G. \& Whitehouse, J.M. 1971. Seed structure and the taxonomy of the Cruciferae. Bot. J. Linn. Soc., 64: 383-409.

Walker, J. \& Doyle, J.A. 1975. The bases of Angiosperm phylogeny: palynology. Ann. Missouri Bot. Gard., 62: 664-723.

Warwick, S.I. \& Anderson, J.K. 1993. Guide to the wild germplasm of Brassica and allied crops. Part II. Chromosome Numbers in the Tribe Brassiceae. Agriculture Canada, Technical Bulletin: 1993-15E, pp. 22. 

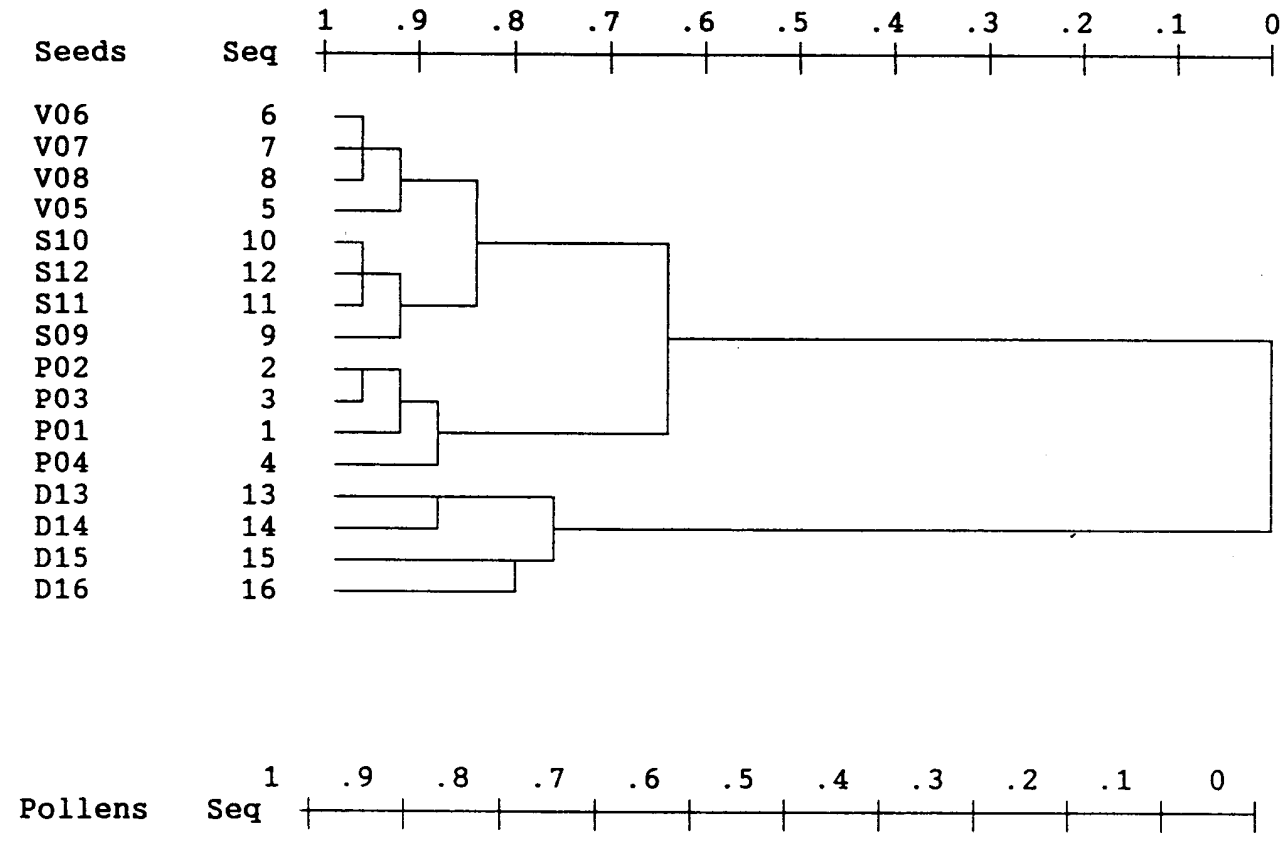

V05

S10

V06

S11

S09

V07

$\mathrm{S} 12$

V08

P02

P04

P01

$\mathrm{P} 03$

D15

D16

D13

D14



Fig. 1. Dendograms based on hierarchical cluster analysis of pollens and seeds belonging to the genus Eruca and Diplotaxis . 

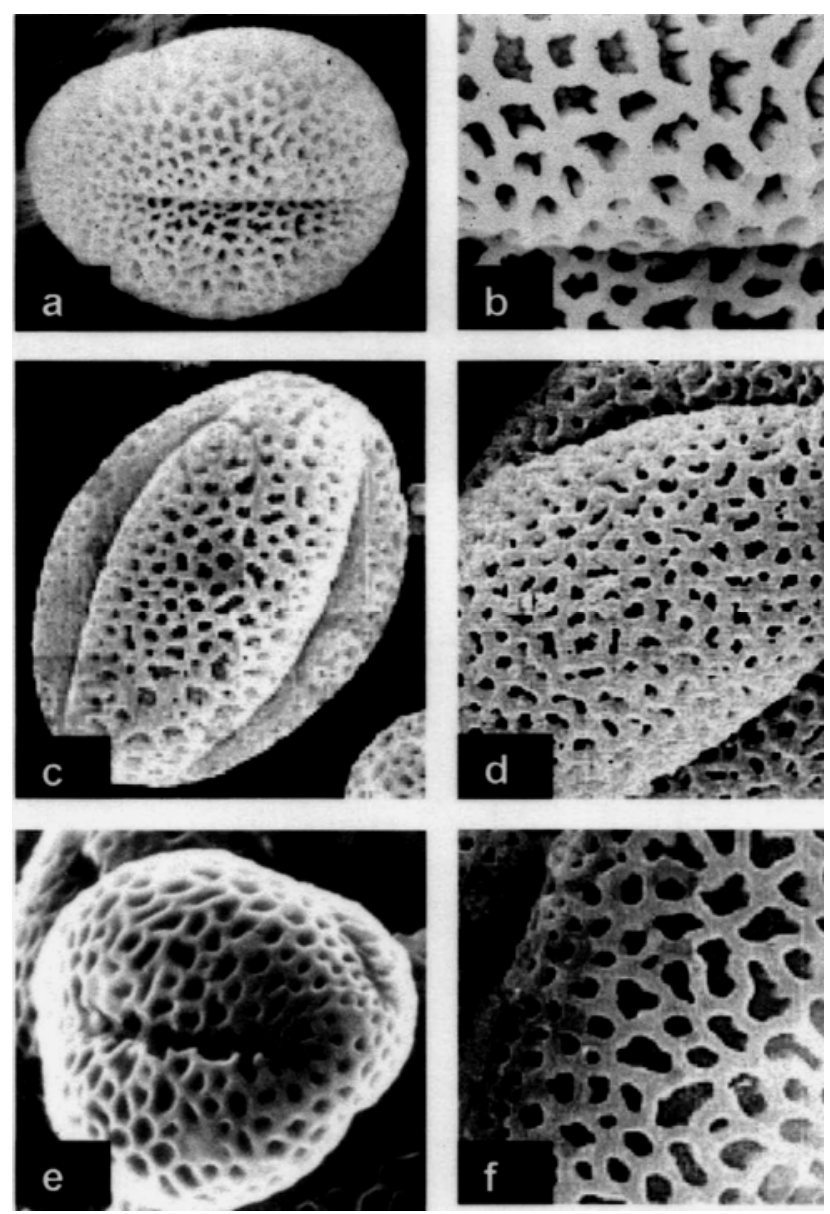

Plate 1: SEM micrographs of pollen grains

a-Eruca pinnatifida f. aurea: equatorial view x 1500;

b- E. pinnatifida f. aurea: reticulum x 10000;

c- E. sativa : equatorial view $\mathrm{x} 1400$;

d- E. sativa : reticulum $\mathrm{x} 8000$;

e- E. vesicaria: polar equatorial view x 1600 ;

f- E. vesicaria: reticulum x 10000 

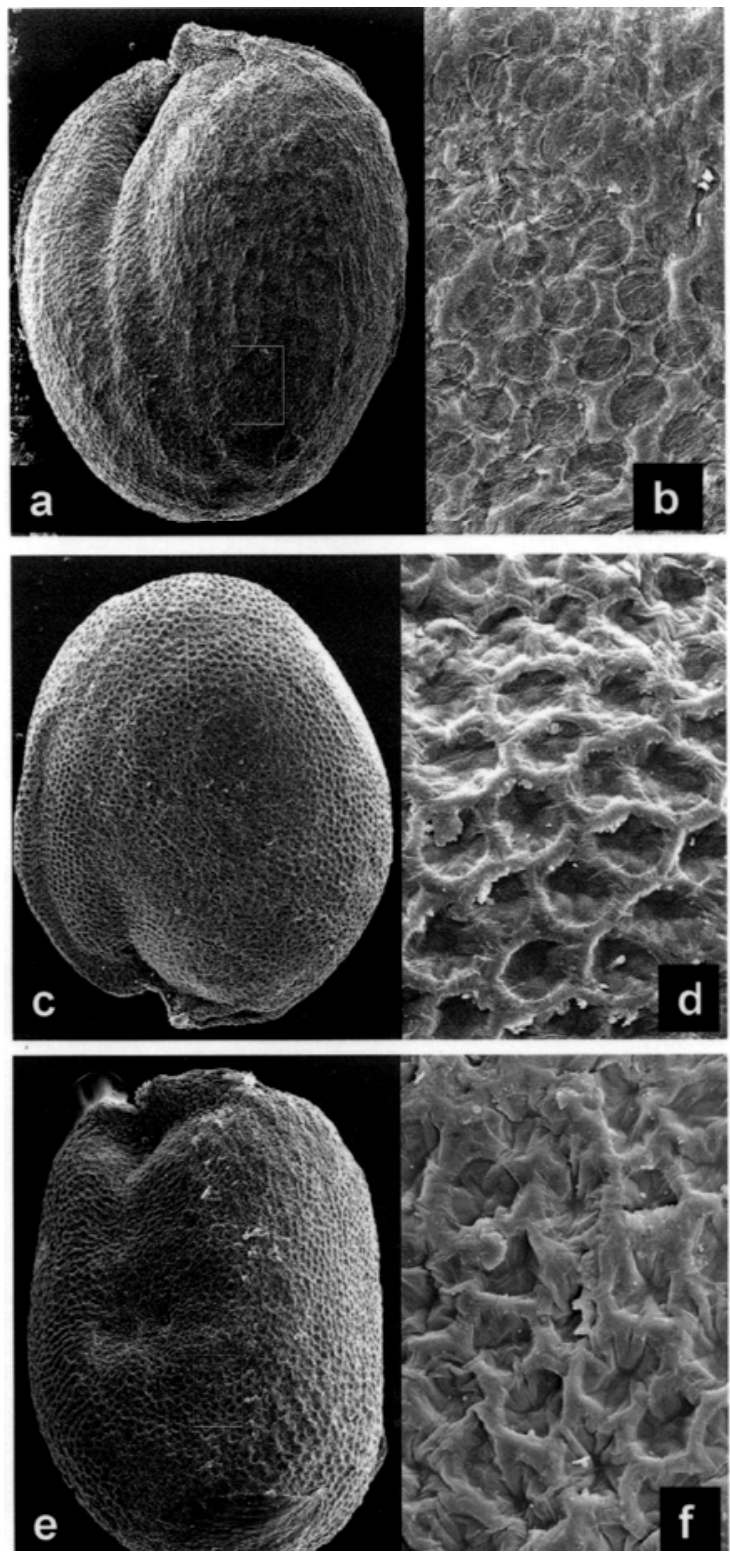

Plate 2: SEM micrographs of seeds

a-Eruca pinnatifida f. aurea: seed x 55;

b- E. pinnatifida f. aurea: regular reticulum with circular lumina x 450;

c- E. sativa : seed x 55;

d- E. sativa : regular reticulum with subcircular lumina $\mathrm{x} 450$;

e- E. vesicaria: seed x 56;

f- E. vesicaria: irregular reticulum and lumina x 520 